\title{
Nonlinear Dynamic Motivation-oriented Taxonomy of L2 Strategies based on Complex Dynamics Systems Theory
}

\author{
Akbar Bahari \\ Bahariakbar2020@gmail.com \\ English Language Teaching Department, University of Qom, Iran
}

\begin{abstract}
The need for a revisited framework of strategies in keeping with the nonlinear dynamic nature of motivational factors in L2 teaching led to the introduction of a taxonomy of nonlinear dynamic motivation-based strategies (NDMSs). This psycho-socio-cultural template suggests discovering dynamic motivational factors at individual level and integrating them into multiple parallel groups within a learner group instead of creating them which is a traditionally established function of motivational strategies to impose superficial cohesion on a learner group without catering for chaotic, emergent and dynamic individual motivational factors. Given the heterogeneity, dynamicity, and nonlinearity of the motivational factors at individual level, the first implication of the study is that NDMSs have the potential to activate identified motivational factors toward an adaptive and autonomous L2 motivation state regardless of their homogeneity or heterogeneity. Secondly, NDMSs have the potential to enable teachers to recruit the learning energy (i.e. motivation) from every member of the group via a dynamic and nonlinear set of motivational strategies instead of imposing a preset set of motivational strategies to all members of the group to elicit/facilitate/encourage equal performance from a motivationally heterogeneous learner group under the pretext of generating a cohesive learner group.
\end{abstract}

Keywords: L2 motivation, nonlinear dynamic motivation-based strategies (NDMSs), complex dynamics systems theory (CDST)

\section{Introduction}

Since a dynamic range of factors (Dornyei, 2009; Ushioda, 2014) are nonlinearly at work in a language learner (Larsen-Freeman \& Cameron, 2008), which differ from one learner to another (de Bot, Lowie, \& Verspoor, 2011), it would be unwise to expect a static behavior from every member of the learner group or to adopt a uniform motivational strategy to motivate them within a linear process. To address the dynamicity and nonlinearity of L2 motivation, L2 teaching needs a taxonomy of strategies to facilitate motivation of every member of the learner group. While L2 motivation has been approached from a variety of aspects either at general or local level, it lacks a sharp and rich focus on nonlinear dynamic motivation (Bahari, 2019a; Cheng \& Dornyei, 2007; Dornyei \& Ryan, 2015). Accordingly, there is a lack of an applicable taxonomy of motivational strategies in keeping with nonlinear dynamic nature of motivational factors to assist teachers in dealing with nonlinearity and dynamicity of motivational factors at individual level rather than group level. Based on complex dynamic systems theories and the complexity of the interactive factors at individual level (Herdina \& Jessner, 2002; 
Jessner, 2006, 2008), applying a single motivational strategy for all learner group cannot be helpful and each learner should be motivated individually with respect to the identified overall identity. Nonlinearity of motivation reflects the unpredictability of motivation state among diverse learner types in terms of the appropriate motivational strategy. Under nonlinearity, no predictable and automatic cause-effect relations exist and no causal connections can be made between triggering events and outcomes (Byrne \& Callaghan, 2014). Studies confirm the nonlinearity of second language learning and that learning comes in spurts (Hohenberger \& Peltzer-Karpf, 2009) without actual coordination (Davis \& Sumara, 2006).

Since learners' linguistic and nonlinguistic systems openly and adaptively interact with other subsystems (Larsen-Freeman, 2015), it is essential to face this unpredictable and variable situation with proportional nonlinear dynamic motivational strategies (NDMSs; see Bahari, 2019a) to enhance L2 motivation. The central plank of the article is the focus on motivational factors at individual level as a response to the current call of research on intra-individual complexity (Serafini, 2017). The emphasis on individual level for identifying motivational factors for nonlinear integration is in keeping with dynamic systems theories which describe the interaction of internal and external factors with respect to motivation as a longitudinal element (Dornyei, 2009). This should not be confused with the ideal L2 self which reportedly (Csizér \& Dörnyei, 2005; Kormos \& Csizér, 2008; Ryan, 2009; Serafini, 2013) has more potential than integrativeness to capture relationships between second language learning and motivational factors. Accordingly, the taxonomy of motivation introduces NDMSs to facilitate identifying motivational factors at individual level instead of preset motivation strategies applied to the whole learner group while expecting the same output. Given the individuality and independence of motivational factors (Dörnyei, 2010; Segalowitz \& Trofimovich, 2012) and nonlinearity and dynamicity of individual differences (Dornyei, Henry, \& Muir, 2016; Dornyei, MacIntyre, \& Henry, 2015; Ushioda \& Dörnyei, 2012), it is necessary to address these factors dynamically and nonlinearly. The proposed taxonomic template facilitates identifying and integrating motivational factors at individual level and supplies the teacher with a wide range of NDMSs proportional to the identified motivational identity. These NDMSs have the potential to create a learner-friendly motivational environment without imposing a single motivational strategy for all learner group regardless of the dynamicity and nonlinearity of L2 motivation. This environment caters for all dynamic and nonlinear motivational factors at individual level while attending to concepts of self-organization, emergence and nonlinearity (van Geert, 2011) by benefiting from the interrelated nature of the factors (Ford, 1992) instead of adopting cliché static motivational strategies (e.g. award, praise, penalty etc.) to create motivation at group level.

\section{The Need to Revisit Motivational Strategies}

Studies on human motivation have developed several taxonomic structures (Chulef et al., 2001; Grouzet., et al., 2005; Schwartz \& Bilsky, 1987; Schwartz, et al., 2012) and accordingly L2 motivation studies have produced different models including Dornyei's (2001) Motivational Strategies and Zimmerman's (2013) motivational regulation strategies which despite their contributions to L2 motivation, have failed to include the concept of nonlinearity and dynamicity of motivational factors in arranging their models. Given the general approval of the significance of Dornyei's Motivational Strategies (Gao et al., 2003; Li, 2009; Ma, 2005) the current study discusses some of its deficient aspects with respect to nonlinearity and dynamicity. Dornyei's (2001) Motivational Strategies in the Language Classroom introduces four motivational aspects which in essence represent ways to create motivation as if motivation is a solid and static concept out there which does not exist and some strategies need to be applied to be created, generated, maintained or encouraged regardless of nonlinearity and dynamicity of motivational factors in L2 teaching. 
The other deficiency of this categorization is that no strategy is suggested to discover latent motivational factors in L2 learner which can be recruited as a tool to enhance language learning. In addition to the lack of strategies to identify learner's motivational factor there is no suggestion concerning the way dynamicity and nonlinearity of learner's motivational factors should be handled. To address this deficiency, a process-oriented model was presented (Dornyei \& Otto, 1998; Dornyei, 2001) which took a dynamic view of motivation in a linear process which ranged from preactional stage to actional and postactional stages. Regardless of the actual context of L2 classroom where a variety of factors are at work to influence learning and teaching, the main deficiency of this processoriented model is ignoring the nonlinear nature of motivational factors (Dornyei, MacIntyre, \& Henry, 2015; Dornyei, Henry, \& Muir, 2016; Ushioda \& Dörnyei, 2012) and lining up motivational functions and influences without considering their multilateral interactions in an actual context of L2 classroom.

Another aspect of Dornyei's taxonomy which contrasts the nonlinearity and dynamicity is its call for creating a cohesive learner group to create a strong 'we' feeling which leads to mutual support (Ehrman \& Dornyei, 1998); however, given the dynamic nature of motivational factors, experiencing such an optimal situation with truly cohesive motivational factors is quite rare if not impossible. Grouping students based on a particular motivational factor observed in one or a few of the learners cannot be generalized and attributed as the cohesive motivational feature. In other words, without motivation diagnosis, motivation compatibility, and motivation integration in advance, we cannot merely group students with nonlinear dynamic motivational factors under the label of cohesive learner group. The term 'group' contradicts the concept of cohesion based on nonlinearity and dynamicity. This should not be interpreted as a negative point but rather as a positive and actual reflection of an actual learning context. We cannot expect a cohesive learner group with all members acting with static commitment to complete a task within a second language learning classroom while believing in the nonlinearity and dynamicity of the motivational factors in second language learning. Eliciting cohesive behaviors by means of motivational strategies from a learning group should not be confused with discovering latent motivational factors at individual level with respect to nonlinearity and dynamicity which influence second language learning. NDMSs move from individual to group at any stage or step of the revisited taxonomy trying to identify the motivational factors, test their compatibility, and integrate them which neither means learner examination in isolation (Triplett, 1898) nor creating group cohesion (Ehrman \& Dornyei, 1998) but rather recruiting group dynamics (Lewin, 1951) based on the learner's self-concept (Csiz'er \& Magid, 2014) which needs to be discovered and directed rather than merely created/generated. Therefore, the proposed framework sets out to capture the multiplicity of factors involved, their nonlinear impact, and their dynamic nature. What makes the proposed taxonomy a better approach for us to understand L2 motivation is the inclusion of dynamicity and nonlinearity of L2 motivation in different strategies from psychosocio-cultural angles. Ignoring the nonlinearity and dynamicity of motivational factors among L2 learners is like expecting/forcing all members of a football team to strike a goal regardless of their positions/capabilities which reflect and represent their actual individual motivational factors.

\section{Theoretical Foundation}

To provide a dynamically oriented taxonomic structure (Hiver \& Al-Hoorie, 2016) NDMSs basically draw on complex dynamic systems theory (de Bot, Lowie, \& Verspoor, 2007; Dornyei, MacIntyre, et al., 2014; Dörnyei, Ibrahim, \& Muir, 2016; Hiver \& AlHoorie, 2016; Larsen-Freeman \& Cameron, 2008; Thompson \& Vasquez, 2015; Thompson, 2017; Serafini, 2017). These strategies are arranged to discover motivational surges at individual level based on the reported influence of motivational operations on the behavior of the individual (Lechago, Carr, Grow, Love, \& Almason, 2010; Rosales \& Rehfeldt, 2007; Wallace, Iwata, \& Hanley, 2006). NDMSs address the nonlinearity and heterogeneity of the learner's behavior instead 
of imposing preset motivational strategies regardless of the individual differences. By mentioning/discussing/reinforcing individual motivational factors, NDMSs facilitate recruiting all components of the motivational superstructure from identified motivational currents described as goal-oriented surges to other intense motivational experiences (Dornyei, Henry, et al., 2015). Given the nonlinearity and dynamicity of motivation at individual level, it needs to be identified in the members of the learning group. In the proposed model, this is done by mentioning/discussing/reinforcing psychosocio-cultural strategies which enable the teacher to come up with a diverse set of dynamic-nonlinear motivational strategies. Following that, the identified motivational factors are examined for compatibility. The main point is that this process is not obsessed by the concept of creating/generating motivation at any cost and instead of eliciting motivational behavior (which is sometimes fake and pretended behavior) from the members of the learner group to form a single cohesive group with a single static motivational feature, NDMSs facilitate approaching learners and discovering their dynamic motivational factors from psychosocio-cultural angles.

\section{NDMSs in Practice}

NDMSs are applied at three stages: premotivational stage, motivational stage, and post-motivational stage. The first stage consists of steps in the order displayed in figure 1 starting by potential motivation diagnosis and ending by nonlinear integration. Drawing on nonlinearity and dynamicity, even the proposed hierarchy allows a dynamic order which means there is no need to complete all steps in a linear process and the order can change dynamically into a nonlinear process based on the discovered motivational factors at individual level among the members of the learner group.

Figure 1. Pre-motivational stage of applying NDMSs.

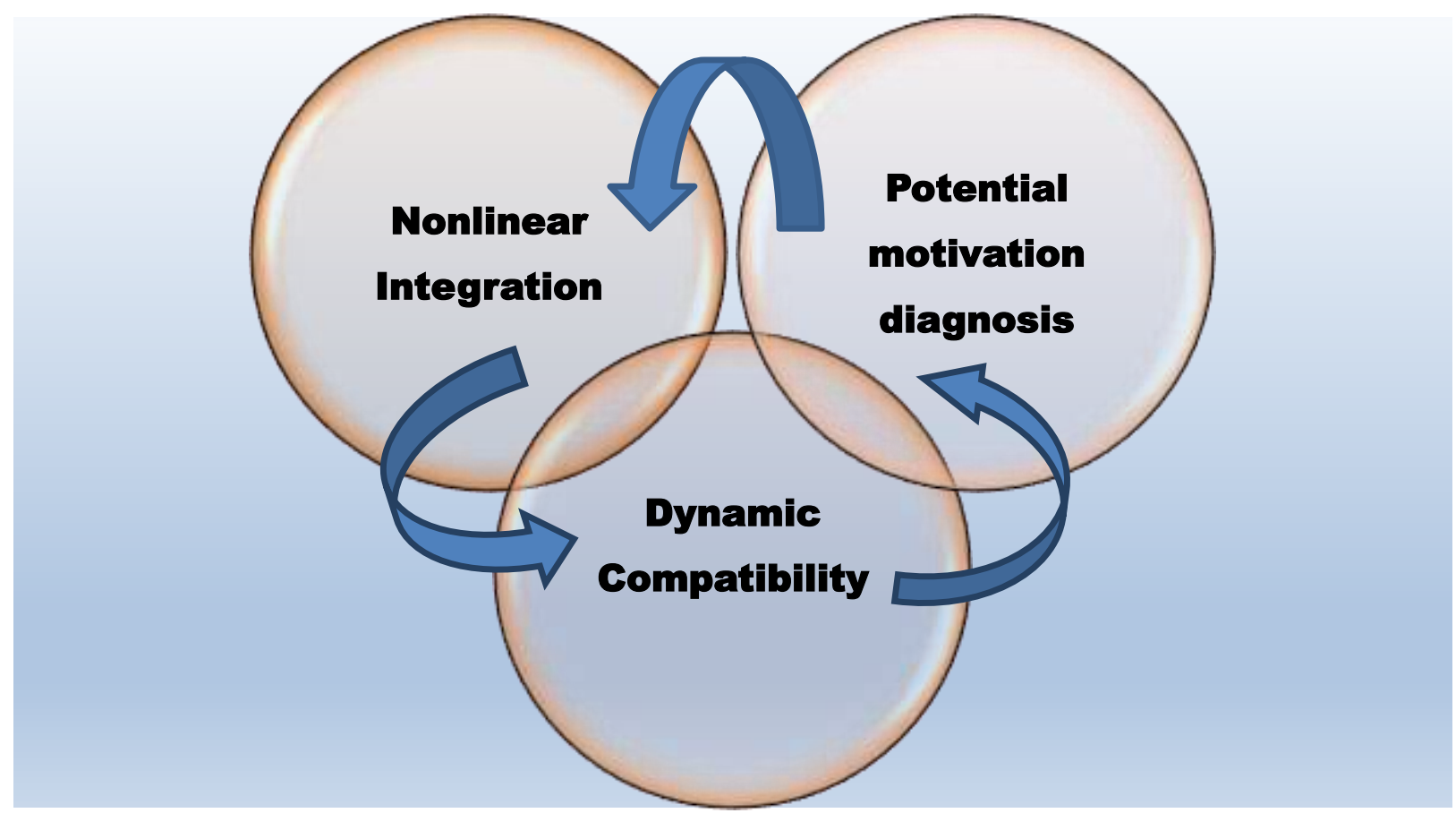

To identify the motivational disposition of L2 learners, the studies suggest the focus on the learners' Motivational Self System (Csizer \& Lukacs, 2010; Dornyei, 2005, 2009; Lamb, 
2012; Thompson \& Erdil-Moody, 2016) and its variations in future studies (Csiz'er \& Magid, 2014; Dornyei \& Chan, 2013; You, Dornyei, \& Csiz'er, 2016) as an important factor in energizing and motivating learning behavior. In diagnosing the motivational factors, we need to identify tedious and boring experiences of the past as well as the attractive and enjoyable experiences of the learners (Dornyei, Ibrahim, \& Muir, 2015), dynamic interactions of the learners with the societal context with respect to the anti-ought-to self (Alharbi, 2017; Huensch \& Thompson, 2017; Lanvers, 2016; Liu \& Thompson, 2018; Thompson \& Liu, 2018; Thompson \& Vasquez, 2015; Thompson, 2017) based on Reactance Theory (Brehm, 1966; Brehm \& Brehm, 1981), the ideal L2 self (Henry, Davydenko, \& Dörnyei, 2015; Waninge, Dörnyei, \& de Bot, 2014) as a dynamic variable which is influenced by continual cognitive-motivational functioning (Dörnyei, 2010; Dörnyei \& Ryan, 2015; LarsenFreeman, 2015). This step is to make sure that previously discovered motivational factors are dynamically compatible in terms of motivational intensity, motivational imagery and motivational behavior (You \& Chan, 2015) with respect to gender differences (Henry \& Cliffordson, 2013; You, Dörnyei, et al., 2016) that can act together/along each other towards a nonlinear dynamic uniformity. Dynamic compatibility of the NDMSs should not be confused with 'cohesive group' which has been used in the literature. While the former is an attempt to find out the rate of compatibility among motivational strategies in order to sort and categorize them under multiple dynamic motivational strategies, the latter is an attempt to group the learners under a single group which is labeled as 'cohesive group' regardless of the nonlinear and dynamic nature of the motivational factor in each and every member of the learning group. The goal is to nonlinearly integrate the previously discovered motivational factors at individual level without trying to form/find a cohesive group. This step draws on group dynamics (Lewin, 1951) and the interplay between individual features, the learning environment, future L2 self-guides, motivational behavior, motivational imagery/visualization, and learning styles (AlShehri, 2009; Dornyei \& Chan, 2013; Kim, 2009; Kim \& Kim, 2011). This needs to be done by highlighting the discovered attractions at individual level and integrating them in consensus with dynamic motivational factors among the members towards a nonlinear dynamic uniformity rather than a static goal.

\section{Motivational Stage of Applying NDMSs}

The NDMSs are categorized into three constructs (cultural, social, and psychological) and each construct consists of several strategies at individual level (see Tables 1,2,3). NDMSs are psycho-socio-cultural-oriented strategies adopted from previous studies (Boekaerts \& Corno, 2005; Eccles et al., 1998; Maehr, 1984; Sansone \& Thoman, 2005; Schwinger, Steinmayr, \& Spinath, 2009; Sivan, 1986; Wentzel, 1999; Zimmerman \& Kitsantas, 2005) based on their efficiency to enhance L2 motivation. These strategies have reportedly self-regulatory potential on the part of the learner (Zimmerman, 2013) along with homogeneously/heterogeneously identified motivational factors on the part of the teacher. NDMSs can sustain the ongoing efforts of the learners towards an adaptive motivation (Wolters, 2003) by exercising the appropriate motivational strategy. The use of learnerfriendly NDMSs prevents reactance and oppositional behavior against the imposed inappropriate motivational strategy on the part of the learner (Bahari, 2018a). The proposed NDMSs can reportedly affect learners' cognitive engagement (Schwinger et al., 2009; Wolters \& Benzon, 2013) as well as interest-enhancement.

\section{Psychological Strategies (PSs)}

Psychological strategies are nonlinearly and dynamically strategized to enhance learner engagement, classroom engagement, and autonomous learning (Legutke \& Thomas, 2013). These strategies are recruited and arranged based on the previous studies to create positive changes in learners' attitudes and motivation (Kim \& Choi, 2006) to lower anxiety in classroom learning (Kim, 2005) and to engender self-efficacy among L2 learners (Cheng, Lam, \& Chan, 2008) in keeping with nonlinear dynamic L2 motivation. The proposed PSs based on previous studies (Katz et al., 2014; Onatsu-Arvolommi et al., 2002) have the potential to enhance self-regulation by identifying and tracking dynamic 
motivational factors at individual level to organize the learning process toward an adaptive type of motivation (e.g. autonomous motivation). Accordingly, the learner is encouraged to unlock the potential of psychological factors by having a goal-specific imagery (Larmer et al., 2015) along with selfefficacy as a significant psychological factor (Rubio, 2014; Mills, 2014; Schunk \& Pajares, 2005) in line with his/her nonlinear dynamic motivational factors. Given the strong correlation between L2 motivation and language anxiety (Cha \& Kim, 2013), this level proposes learning-teaching readjustment by assigning a psychologically-well-informed teacher for psychological needs and concerns of the learners.

The following tables show the psycho-sociocultural strategies with their theoretical bases at individual level which are applied either by mentioning/discussing/reinforcing by the teacher:

Table 1. Psychological strategies

\begin{tabular}{|c|c|c|}
\hline \multicolumn{3}{|c|}{ Psychological Strategies } \\
\hline Theoretical basis & Concept & Strategy \\
\hline \multirow{7}{*}{$\begin{array}{l}\text { Self-efficacy } \\
\text { theory } \\
\text { (Bandura, 1997) }\end{array}$} & One’s capabilities & \multirow{25}{*}{$\begin{array}{l}\text { Teachers are suggested to } \\
\text { take the following steps to } \\
\text { strategize and contextualize } \\
\text { every step: } \\
\text { First, } \\
\text { Mention/Discuss/Reinforce } \\
\text { dynamic, nonlinear, and } \\
\text { motivating psychological issues } \\
\text { at individual level } \\
\text { Second, E } \\
\text { Encourage/Facilitate/Scaffold } \\
\text { exchanging and introducing } \\
\text { ysychologically motivating } \\
\text { factors at group level } \\
\text { For example, to contextualize the } \\
\text { concept of One's capabilities, } \\
\text { students' sense of colf-efficacy is } \\
\text { strengthened via mastery } \\
\text { experiences which is strategized } \\
\text { according to the above steps. }\end{array}$} \\
\hline & Others' capabilities & \\
\hline & self-monitoring strategies & \\
\hline & self-regulating strategies & \\
\hline & self-evaluation strategies & \\
\hline & spatiotemporal complexity of language & \\
\hline & self-regulated language learning & \\
\hline \multirow[t]{6}{*}{$\begin{array}{l}\text { Attribution theory } \\
\text { (Weiner, 1992) }\end{array}$} & $\begin{array}{l}\text { the causes of previous success and } \\
\text { failure }\end{array}$ & \\
\hline & Goal-orientation & \\
\hline & Hopefulness & \\
\hline & Agentic persistence & \\
\hline & Purposefulness & \\
\hline & Zone of proximal development & \\
\hline \multirow{5}{*}{$\begin{array}{l}\text { Self-worth theory } \\
\text { (Covington, 1998) }\end{array}$} & Motivational behavior & \\
\hline & Face-saving behavior & \\
\hline & Goal-setting & \\
\hline & Motivational factors & \\
\hline & Intrinsic and extrinsic motivatin & \\
\hline \multirow{7}{*}{$\begin{array}{l}\text { Snyder's hope } \\
\text { theory ( } 2002)\end{array}$} & Desire and expectation & \\
\hline & Ambition & \\
\hline & Positive emotions & \\
\hline & Demoralization & \\
\hline & Incompetency & \\
\hline & Despair & \\
\hline & Helplessness & \\
\hline
\end{tabular}

\section{Social Strategies (SSs)}

Social strategies enable L2 learners to use L2 for sociolinguistic goals (e.g. expression/ comprehension of social emotions, social thoughts, and social activities in keeping with other studies (e.g., Joe, Hiver, \& Al-Hoorie, 2017). This is done via project-based learning in the classroom setting with intensified motivation (Stoller, 2006) in accord with 
nonlinearity and dynamicity of L2 motivation with respect to sociolinguistic goals. To this end, experiential learning and interaction (Legutke \& Thomas, 2013) in a collaborative effort and performance (Beckett \& Slater, 2005 ) is encouraged. This is to master language, content, and skill via individual and group activities with respect to learning process (Larmer, Mergendoller, \& Boss, 2015) and nonlinearity and dynamicity of motivation (Bahari, 2018b). This also provides learners with nonlinear dynamic motivation (Bahari, 2019b) while directing the learning process in a dynamic way (Kaldi, Filippatou, \& Govaris, 2011) and considering the need to produce tangible products on the part of learners (Markham, Larmer, \& Ravitz, 2003) with enhanced sense of self-fulfillment (Schmidt, Loyens, van Gog, \& Paas, 2007). This level enables learners to share their experiences and understandings as well as to construct meaning by assigning a socially-well-informed teacher to cater for social needs and concerns of the learners.

Table 2. Social Strategies

\begin{tabular}{|c|c|c|}
\hline \multicolumn{3}{|c|}{ Social Strategies } \\
\hline Theoretical basis & Concept & Strategy \\
\hline \multirow{13}{*}{$\begin{array}{l}\text { Social motivation theory } \\
\text { (Wentzel, 1999) }\end{array}$} & Social goal & \multirow{33}{*}{$\begin{array}{l}\text { Teachers are suggested to take } \\
\text { the following steps to strategize } \\
\text { and contextualize every step: } \\
\text { First, Mention/Discuss/Reinforce } \\
\text { dynamic, nonlinear, and } \\
\text { motivating social issues at } \\
\text { individual level } \\
\text { Second, } \\
\text { Encourage/Facilitate/Scaffold } \\
\text { exchanging and introducing } \\
\text { socially motivating factors at } \\
\text { sroup level ex } \\
\text { Fur example, to contextualize the } \\
\text { contept of Social goal, students' } \\
\text { social soal is strengthened via } \\
\text { setting sonre goals which is } \\
\text { strategized according to the above } \\
\text { steps. }\end{array}$} \\
\hline & Social conformity & \\
\hline & Social autonomy & \\
\hline & Social self-concept & \\
\hline & Social responsibility & \\
\hline & Social relationship & \\
\hline & Social resource/position equity & \\
\hline & Social safety & \\
\hline & Social mastery & \\
\hline & Social management & \\
\hline & Social superiority & \\
\hline & Social self-determination & \\
\hline & Self-assertive social relationship & \\
\hline \multirow{15}{*}{$\begin{array}{l}\text { Goal orientation theory } \\
\text { (Ames, 1992) }\end{array}$} & Social self-acceptance & \\
\hline & Social mores & \\
\hline & Social affiliation & \\
\hline & Community feeling & \\
\hline & Social recognition & \\
\hline & Well-being & \\
\hline & Self-actualization & \\
\hline & Appearance & \\
\hline & Social events & \\
\hline & Social activities & \\
\hline & Social relationship goals & \\
\hline & Social goals & \\
\hline & Nonlinearity in time and space & \\
\hline & Social supremacy & \\
\hline & Social values & \\
\hline \multirow{5}{*}{$\begin{array}{lrr}\begin{array}{l}\text { Theory of } \\
\text { motivation }\end{array} & \text { social } \\
\text { 1994) } & & \end{array}$} & Social appropriateness & \\
\hline & Social morality & \\
\hline & Social behavior & \\
\hline & Social competence & \\
\hline & Social efficacy & \\
\hline
\end{tabular}




\begin{tabular}{ll}
\hline & Social outcomes \\
\hline Theory of planned & Social pressure \\
behavior (Ajzen, 1988; & Perceived behavior \\
\cline { 2 - 2 } Eagly \& Chaiken, 1993) & Self-regulatory skills \\
\hline
\end{tabular}

\section{Cultural Strategies (CSs)}

Cultural strategies require teachers to mediate in a joint activity with learners while trying to understand the learners' cultural orientation, cultural attitudes, sources of difficulty, and appropriate types of mediation with respect to nonlinear dynamic motivational factors on the part of learners at individual level (Bahari, 2018c). This construct proposes learning-teaching readjustment by assigning a culturally-well-informed teacher for cultural needs and concerns of the learners instead of a culturally-prejudiced teacher who preaches anti-cultural views. Mentioning/discussing/reinforcing identified cultural strategies creates a mutual understanding between learners with diverse cultural values.

Table 3. Cultural strategies

\begin{tabular}{|c|c|c|}
\hline \multicolumn{3}{|c|}{ Cultural Strategies } \\
\hline Theoretical basis & Concept & Strategy \\
\hline \multirow{4}{*}{$\begin{array}{l}\text { Young's (1994) } \\
\text { motivation models }\end{array}$} & Cultural events & \multirow{15}{*}{$\begin{array}{l}\text { Teachers are suggested to } \\
\text { take the following steps to } \\
\text { strategize and contextualize } \\
\text { every step: } \\
\text { First, } \\
\text { Mention/Discuss/Reinforce } \\
\text { dynamic, nonlinear, and } \\
\text { motivating cultural issues at } \\
\text { individual level } \\
\text { Second, } \\
\text { Encourage/Facilitate/Scaffold } \\
\text { exchanging and introducing } \\
\text { cylturally motivating factors } \\
\text { at group level } \\
\text { For enample, to contextualize } \\
\text { the convent of Cultural } \\
\text { events, students motivating } \\
\text { cultural event is strengthened } \\
\text { via describing the cultural } \\
\text { event which is strategized } \\
\text { according to the above steps. }\end{array}$} \\
\hline & Cultural activities & \\
\hline & $\begin{array}{l}\text { L2 culture } \\
\text { State of motivation }\end{array}$ & \\
\hline & Additive bilingualism & \\
\hline \multirow{5}{*}{$\begin{array}{l}\text { Gardner's (1985) } \\
\text { orientation theory }\end{array}$} & Sacred text & \\
\hline & $\begin{array}{lll}\text { engagement in } \\
\text { activities }\end{array}$ & \\
\hline & Culture of learning a foreign language & \\
\hline & $\begin{array}{l}\text { Culture of the speakers of a foreign } \\
\text { language }\end{array}$ & \\
\hline & Cultural values of the foreign language & \\
\hline \multirow{6}{*}{$\begin{array}{l}\text { Maslow's (1970) } \\
\text { hierarchy of need }\end{array}$} & Cultural diversity & \\
\hline & Cultural exploration & \\
\hline & Cultural secrets & \\
\hline & Cultural contradictions & \\
\hline & Cultural clashes & \\
\hline & Cultural supremacy & \\
\hline
\end{tabular}

Post-motivational stage of applying NDMSs provides a nonlinear dynamic picture of the steps which should be taken (as far as nonlinearity and dynamicity allows us) to reach the final goal of motivating L2 learners. 
Figure 2. Post-motivational stage of applying NDMSs.

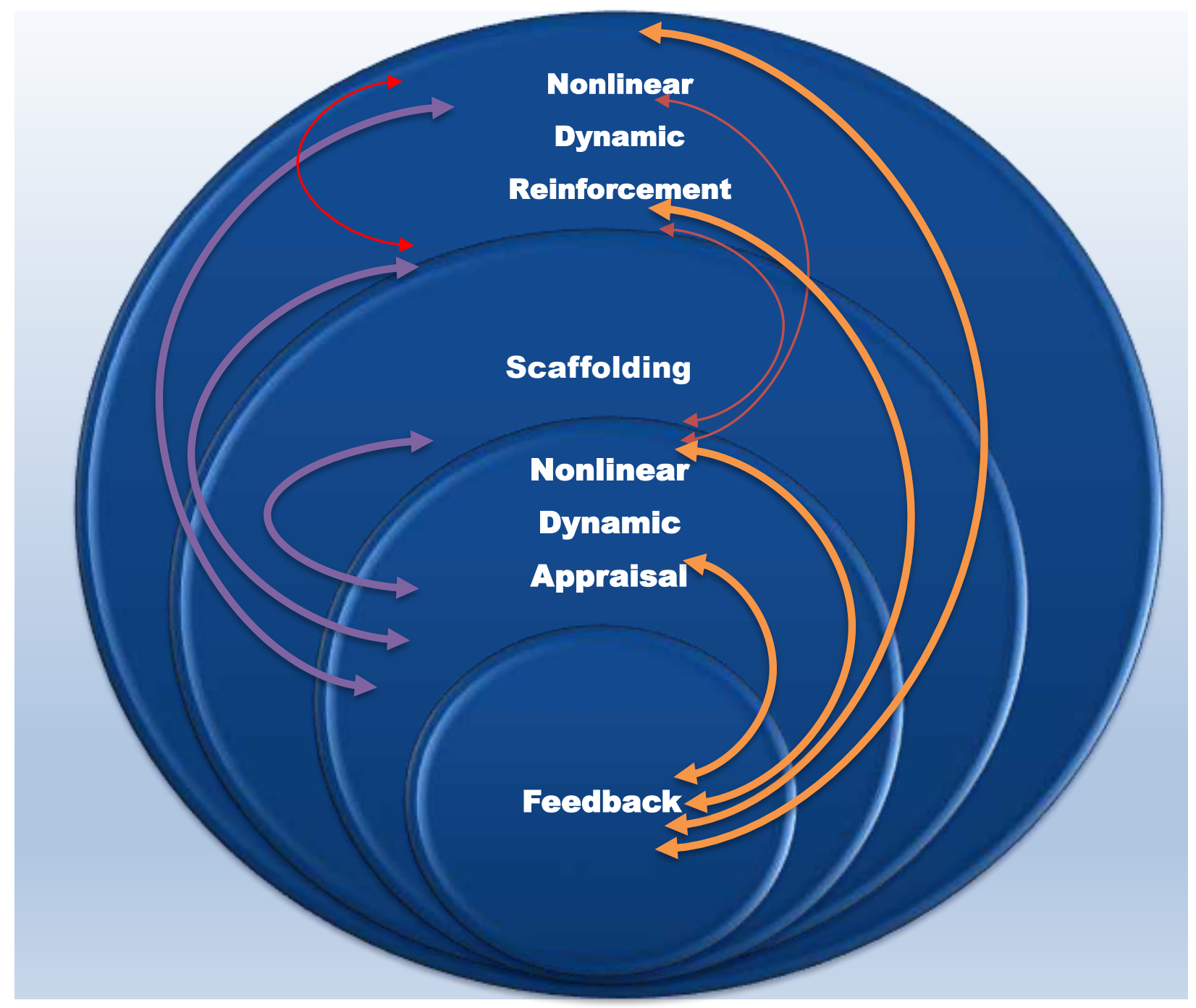

The identified motivational factors need to be nonlinearly and dynamically addressed to provide L2 learners with required feedback with respect to identified goals, tendencies, preferences, desirability, etc. Individual learner differences need to be considered while giving feedback (Dörnyei, 2010) which is the focal point of the current study from identifying the motivational factors to the nonlinear dynamic motivational reinforcement. To this end, NDMSs-based instructions for teachers (see table 4) provide a number of instructions to provide feedback in an integrative psycho-socio-cultural approach. Nonlinear dynamic appraisal aims at processing and organizing identified motivational factors in parallel groups (e.g. psychological motivational factors and social motivational factors) towards multiple dynamic L2 teaching-learning goals (e.g. writing goals for some and speaking goals for some others). As the second step, nonlinear dynamic appraisal serves to activate action control strategies to facilitate the execution process (Dörnyei \& Tseng, 2009). Drawing on sociocultural theory (Lantolf, 2000; Swain, 1997), scaffolding within NDMSs encourages language construction through collaborative dialogue which is assisted (Basturkmen, Loewen, \& Ellis 2002) and orchestrated by a motivational teacher by creating motivating interactions including triadic interaction (Van Lier, 2002) as an optimal setting to integrate previously processed motivational factors by scaffolding and preparing them for reinforcement. Nonlinear dynamic reinforcement aims at conscious announcement of the identified, appraised, 
scaffolded, and feedbacked motivational factors at individual level. The conscious expression of nonlinear dynamic motivational factors at individual level not only reinforces this power in the learner but also creates a sense of self-recognition which is highly significant under the taxonomy of NDMSs, where it is discovered and included in L2 teaching-learning.

\section{Pedagogical Guidelines}

\section{Pre-Motivational Stage: Mentioning Identified Motivational Factor}

At this stage, teachers are suggested to try different psycho-socio-cultural strategies (see tables $1,2,3$ ) for every member of the learning group and identify the motivational identity and related motivational factors in every student. To this end, teachers are suggested to mention/discuss/reinforce dynamic, nonlinear, and motivating psycho-sociocultural issues at individual level. Following that teachers are suggested to encourage/facilitate/scaffold exchanging and introducing psycho-socio-cultural motivating factors at group level. To contextualize the introduced concepts, students' psycho-sociocultural motivating factors need to be addressed according to the suggested steps. Accordingly, teachers are suggested to begin with an elicitation rather than reformulation (Lyster, 2004) and engage learners in multitasking to give 'voice' to the learners' experience (Levy, 2015). This provides the learner with a chance to increase self-efficacy among the learner group, which can be reinforced by encouraging the use of communicative strategies to manage learning problems (Nakatani \& Goh, 2007). Accordingly, encourage communicative responses with adaptation, interpretation, paraphrasing and addition of new information rather than meaningful responses. To this end, a single linguistic feature should be addressed at a time (Ellis, 2009) to facilitate learning and to avoid unmanageable cognitive load. Accordingly, engage learners in strategic planning to internalize L2 structure (Seifoori \& Vahidi, 2012). Plan pre-listening activities to activate learners' script and get to know learners' motivational features. PSs are arranged to encourage metacognitive strategies to build meaning (Graham, 2006). To facilitate comprehension process, encourage learners to overcome the compulsion to translate (Liu, 2003) and avoid applying L1 segmentation procedures to the rhythmically different target language (Cutler, 2001). Encourage natural target language reproduction rather than echoing, imitating or slavish mimicry (Kim, 2011). Encourage the use of language skills instruction strategy to improve skills proficiency (Harris, 2007). To increase input in naturalistic settings (Flege, 2009), encourage learners to pay attention to pause-bounded units to facilitate listening comprehension rather than syntactic cues (Harley, 2000). Encourage learners to selectively work on linguistic features which are related to comprehensibility rather than linguistic nativelikeness (Saito, 2015). To enhance in-field learning encourage information exchange via location-based learning systems (Burston, 2014) and encourage making questions that require evaluation and reaction rather than recall of details.

\section{Motivational Stage: Discussing Identified Motivational Factor}

At this stage, teachers are suggested to discuss the identified motivational factors with other members of the learner group to increase their knowledge about different motivational identities in the classroom with respect to the strategies suggested above (see tables 1, 2, 3). Teachers are suggested to approach the cultural contexts and the learning needs of learners (Lopes-Murphy, 2012) to engage them at second language learning by mentioning/discussing/ reinforcing the identified motivational factors.

To avoid demotivation, we need to avoid disparaging social and cultural values, which can make students feel disfranchised (Kana'iaupuni, Ledward, \& Jensen, 2010). To develop self-efficacy, encourage second language learners to inhabit an identity of a fluent speaker by imitating body movements (McCafferty, 2008) and encourage global comprehension rather than partial comprehension. Since the goal is to process the speech rather than retrieve the information from the long-term memory, visualize and 
enact pronunciation phenomena by the use of instructional gestures (Smotrova, 2017). Promote new ways of thinking which necessarily involve both forms of mediation operating in tandem. Encourage experiential learning and interaction (Legutke \& Thomas, 2013) by mentioning/discussing/reinforcing the identified motivational identity via psychosocio-cultural motivational strategies. Accordingly, develop ideal selves along with ought-to selves among learners based on the positive relationship between them and the desire to improve pronunciation in a foreign language (Huensch \& Thompson, 2017). Keep encouraging students to see learning as an enjoyable process (Zhang, et al., 2016) and mention/discuss/reinforce the identified motivational identity via psycho-socio-cultural motivational strategies. Individual learner differences need to be considered while giving feedback (Dörnyei, 2010). Include social and cultural factors to make learning an important and meaningful task for learners (Gay, 2010).

\section{Post-Motivational Stage: Reinforcing Identified Motivational Factor}

At this stage, teachers are suggested to reinforce different identified motivational factors for every member of the learning group and benefit from the enhanced motivation for L2 teaching via the suggested strategies (see tables 1, 2, 3).

To reinforce autonomous motivation, encourage participation in communicative activities and remove scaffolding in line with real-life listening experience (Field, 2007). Encourage communicative responses with adaptation, interpretation, paraphrasing and addition of new information rather than meaningful responses. Appreciate cultural differences and promote the motivation and agency of individual learners in the classroom context (Ushioda, 2013). Provide learners with opportunities to manage their emotions, thought processes, and actions (e.g., Joe, Hiver, \& Al-Hoorie, 2017); and encourage imitation so that learners can use the imitated content for their own communicative purposes (Smotrova, 2017). Accordingly, develop agency by reinforcing belief in one's competence (Mercer, 2015); encourage leaner autonomy by developing agency (Benson,
2007) and develop strategy knowledge to facilitate learning management (Ryan \& Irie, 2014). Inform learners that accent is a normal characteristic of L2 speech production (Abrahamsson \& Hyltenstam, 2009) which should not act as a demotivating factor, and encourage learners' control over learning management to ensure a learner-friendly instruction (Mercer, 2015). Accordingly, conduct in-depth language counselling to facilitate learner autonomy, strategies and goal (O’Reilly, 2012). To enhance in-field learning encourage information exchange via location-based learning systems (Burston, 2014), and encourage producing modified comprehensible output via interactional strategies (Pica, 2002). To reinforce the identified motivational factors, encourage the use of interactional strategies to facilitate meaning negotiation (Swain, 1995). Encourage hopeful thinking among the learners to change the present attitudes to shape positive thinking (Oxford, 2017) and encourage strategic competence to enhance hope among learners (Oxford, 2017). To encourage motivational learning develop growth mindsets among the learners (Dweck, 2006) and improve teacher-learner alliance to nullify hopelessness (Ehrman, 1998). Encourage interactive systems as subcategories of complex systems at different levels (Larsen-Freeman, 2017) as well as goaldirectedness towards authentic complexity of learning (Oxford, 2017), and finally, encourage learner self-regulation over motivation (Panadero \& Alonso-Tapia, 2014) by exercising different types of proposed NDMSs.

The proposed taxonomy tried to address the nonlinearity and dynamicity of L2 motivation from three perspectives. At social level, social cognitive theories (Boo, Dornyei \& Ryan, 2015) were adapted to integrate learners' purposeful relational activity with their ongoing participation in social practices which vary from one learner to another. At psychological level, problem-based L2 motivation and students-oriented learning were emphasized to mediate learner's psychological functioning rather than mere scaffolding (Lantolf \& Thorne, 2006) with respect to the nonlinearity and dynamicity of L2 motivation. Accordingly, at cultural level, with a focus on Vygotskian socio-cultural 
theory along with mediated learning experience, mediated learning experience was provided to meet the needs of learners from different cultural backgrounds (Feuerstein et al., 2010) along with social environment to enable learners to formulate relationships between the perceived facts (Feuerstein et al., 1997). The previous studies have approached second language learning and motivation either with respect to strategies (Dornyei \& Ryan, 2015; Griffiths, 2013; Oxford, 2017; Quoidbach, Mikolajczak, \& Gross, 2015; Schunk \& Zimmerman, 2012) or as a static factor (Moskovsky et al., 2016) or a learnercontext interaction subject (Thompson \& Vasquez, 2015; Thompson \& Erdil-Moody, 2016) or introducing influential factors (Lyubomirsky \& Layous, 2013; Sheldon, Boehm, \& Lyubomirsky's, 2013; Rusk \& Waters, 2015). Despite approaching the nonlinear dynamic nature of L2 motivation (Ushioda \& Dörnyei, 2012) they have not integrated this critical feature of L2 motivation in a single learning model or a taxonomy of L2 learning strategies. The advantages of the proposed NDMSs lie in several revisited aspects of motivational strategies which are used to either solely overemphasize selfregulated organization without assigning an actual facilitative role for L2 teachers or ignore the highly significant concepts of nonlinearity and dynamicity which possess the potential to metamorphose traditionally established L2 teaching-learning and assessment to a large extent. In contrast to the cybernetic model of the self-regulation of behavior suggesting the hierarchical organization of goals where lower goals are less frequently functional compared to higher goals guiding more related behavior (Carver \& Scheier, 1998), NDMSs suggest nonlinear-dynamic organization of motivational factors to ensure unlocking the potential of all motives regardless of their position in any proposed categorization. Taxonomic structures drive studies both at theoretical level and practical level (Digman, 1997; Goldberg, 1981). Accordingly, the taxonomy of NDMSs ensure enhanced motivation at individual level and integrated multiple homogeneous/heterogeneous clusters of energizing motives (Fiske, 2004; Fiske, 2008) towards dynamic and emergent goals with the least rate of learning anxiety.

\section{Conclusion}

Drawing on the complex dynamic systems theory as a variation of Complexity Theory, the present study presented NDMSs as a revisited taxonomy for second language teaching. The proposed strategies have the potential to be used for classroom setting and CALL setting as well as other teaching purposes beyond language teaching. The proposed strategies keep identified motivational factors at individual level in motion to create a motivation-oriented L2 teaching-learning context. Accordingly, NDMSs provide a truly learner-friendly L2 teaching via a new template of strategies to cater for learners' emergent and dynamic motivational identity without trying to shape them based on a preset used-for-all strategy. It is against the dynamicity of motivational identity to expect all members of a learner group to show equal output or assess them based on a preset usedfor-all strategy. It is also against nonlinearity of motivational factors to apply static linear strategies and expect a truly diversely motivated learner group where all motivational identities are democratically mentioned/discussed/reinforced. Despite the apparent chaotic state of NDMSs, they have the potential to meet dynamic motivational needs of L2 learners by producing a nonlinearlydynamically motivated learner, nonlinearlydynamically motivating teacher, and nonlinearly-dynamically motivational classroom.

\section{Acknowledgments}

The author would like to thank the anonymous reviewers for their insightful comments and suggestions to improve the paper. He also wishes to thank his wife and daughter, Mona and Anahita for their support. 


\section{References}

Abrahamsson, N., \& Hyltenstam, K. (2009). Age of acquisition and nativelikeness in a second language - listener perception $v s$. linguistic scrutiny. Language Learning, 59, 249-306.

Ajzen, I. (1988). Attitudes, personality and behavior. Chicago: Dorsey Press.

Alharbi, F. (2017). The dynamics of the L2 motivational self-system among Saudi study abroad students (Unpublished doctoral dissertation). Tampa, FL: University of South Florida.

Al-Shehri, A. H. (2009). Motivation and vision: The relation between the ideal L2 self, imagination and visual style. In Z. Dornyei \& E. Ushioda (Eds.), Motivation, language identity and the L2 self (pp. 164-171). Bristol, UK: Multilingual Matters.

Ames, C. (1992). Classrooms, goals, structures and student motivation. Journal of Educational Psychology, 84, 267-271.

Bahari, A. (2019a). FonF practice model from theory to practice: CALL via focus on form approach and nonlinear dynamic motivation to develop listening and speaking proficiency. Computers \& Education, 130(3), 40-58. doi.org/10.1016/j.compedu.2018.11.009

Bahari, A. (2019b). Psychological Reactance Management via Nonlinear Dynamic Motivation in Classroom and Telecollaborative Second Language Learning Contexts. Journal of educational, health and Community Psychology, 8(1), 40-58.

Bahari, A. (2018a). Nonlinear dynamic motivation-oriented telecollaborative model of language learning via formulaic sequences to foster learner autonomy. The Journal of Teaching English with Technology. 18(3), 65-81, http://www.tewtjournal.org

Bahari, A. (2018b). Sacred text motivation for general 12 learners: a mixed methods study. Journal of Academic Ethics, 16(4), 1-31. doi.org/10.1007/s10805-0189316-3

Bahari, A. (2018c). Developing listening and speaking via a psycho-socio-cultural learning model based on non-linear dynamic motivation. Jordan Journal of Modern Languages and Literature, 10(2), 115-135.

Basturkmen, H., Loewen, S., \& Ellis, R. (2002). Metalanguage in focus on form in the communicative classroom. Language Awareness, 11(1), 1-13.

Beckett, G. H., \& Slater, T. (2005). The project framework: A tool for language, content, and skills integration. ELT Journal, 59, 108-116.

Benson, P. 2007. Autonomy in Language Teaching and Learning: State of the Art. Language Teaching 40(1), 21-40. doi:10.1017/s0261444806003958

Boekaerts, M., \& Corno, L. (2005). Selfregulation in the classroom: A perspective on assessment and intervention. Applied Psychology: An International Review, 54, 199-231.

Boo, Z., Dornyei, Z., \& Ryan, S. (2015). L2 motivation research 2005-2014: Understanding a publication surge and a changing landscape. System, 55, 145-157.

de Bot, K., Lowie,W., \& Verspoor, M. (2007). A dynamic systems theory approach to second language acquisition. Bilingualism: Language and Cognition, 10(1), 7-21.

de Bot, K., W. Lowie, and M. Verspoor. (2011). "Introduction." In A Dynamic Approach to Second Language Development: Methods and Techniques, edited by M. H. Verspoor, K. de Bot, and W. Lowie, 1-23. Amsterdam: John Benjamins.

Brehm, J. W. (1966). A theory of psychological reactance. New York: Academic Press. 
Brehm, S., \& Brehm, J. W. (1981). Psychological reactance: A theory of freedom and control. New York, NY: Academic Press.

Burston, J. (2014). MALL: the pedagogical challenges. Computer Assisted Language Learning, 27, 344-357.

Byrne, D., \& Callaghan, G. (2014). Complexity theory and the social sciences: The state of the art. New York, NY: Routledge.

Cha, J. S., \& Kim, T. Y. (2013). Effects of English e-learning motivation and language anxiety of elementary school students on willingness to communicate in English and English speaking. Primary English Education, 19, 271-294.

Carver, C. S., \& Scheier, M. F. (1998). On the Self-regulation of Behavior. Cambridge, England: Cambridge University Press.

Cheng, H. F., \& Dornyei, Z. (2007). The use of motivational strategies in language instruction: The case of EFL teaching in Taiwan. Innovation in Language Learning and Teaching, 1(1), 153-174. doi.org/10.2167/illt048.0

Cheng, R. W., Lam, S., \& Chan, J. C. (2008). When high achievers and low achievers work in the same group: The roles of group heterogeneity and processes in projectbased learning. British Journal of Educational Psychology, 78, 205-221.

Chulef, A., Read. S., Walsh. D. (2001). A hierarchical taxonomy of human goals. Motivation and Emotion. 25(3), 191-232.

Clarke, D. (2003). Faith and Hope. Australian Psychiatry, 11(2), 164-168.

Covington, M. (1992). Making the Grade: A SelfWorth Perspective on Motivation and School Reform. Cambridge, England: Cambridge University Press.

Csizér, K., \& Dörnyei, Z. (2005). The internal structure of language learning motivation: Results of structural equation modeling. Modern Language Journal, 89, 19-36.
Csizer, K., \& Lukacs, G. (2010). The comparative analysis of motivation, attitudes and selves: The case of English and German in Hungary. System, 38(1), 113.

Csizer, K., \& Magid, M. (Eds.). (2014). The impact of self-concept on language learning. Bristol, UK: Multilingual Matters.

Cutler, A. (2001). Listening to a second language through the ears of a first. Interpreting 5, 1-23.

Davis, B., \& Sumara, D. J. (2006). Complexity and education: Inquiries into learning, teaching, and research. Mahwah, NJ: Lawrence Erlbaum.

Digman, J. M. (1997). Higher-order factors of the Big Five. Journal of Personality and Social Psychology, 73(6), 46-56.

Dörnyei, Z. (2001). Motivational strategies in the language classroom. Cambridge, England: Cambridge University Press.

Dörnyei, Z. (2009). The L2 motivational self system. In Z. Dörnyei \& E. Ushioda (eds.), 9-42.

Dörnyei, Z. (2010). The relationship between language aptitude and language learning motivation: Individual differences from a Dynamic Systems perspective. In E. Macaro (Ed.), Continuum companion to second language acquisition (pp. 247267). London: Continuum.

Dörnyei, Z., \& Chan, L. (2013). Motivation and vision: An analysis of future L2 selfimages, sensory styles, and imagery capacity across two target languages. Language Learning, 63, 437-462. doi:10.1111/lang.12005

Dörnyei, Z., Henry, A., \& Muir, C. (2016). Motivational currents in language learning: Frameworks for focused interventions. New York: Routledge.

Dörnyei, Z., Ibrahim, Z., \& Muir, C. (2015). Directed Motivational Currents: Regulating complex dynamic systems 
through motivational surges. Cambridge, UK: Cambridge University Press.

Dörnyei, Z., \& I. Otto (1998). Motivation in action: A process model of $\mathrm{L} 2$ motivation. Working Papers in Applied Linguistics (Thames Valley University, London), 4, 4369.

Dörnyei, Z., \& Kubanyiova, M. (2014). Motivating learners, motivating teachers: The role of vision in language education. Cambridge, UK: Cambridge University Press.

Dörnyei, Z., MacIntyre, P. D., \& Henry, A. (2015). Motivational dynamics in language learning. Bristol, England: Multilingual Matters.

Dörnyei, Z., \& Ryan, S. (2015). The psychology of the language learner revisited. New York, NY: Routledge.

Dörnyei, Z., \& Tseng, W.-T. (2009). Motivational processing in interactional tasks. In A. Mackey \& C. Polio (Eds.), Multiple perspectives on interaction: Second language research in honor of Susan M. Gass (pp. 117-134). Mahwah, NJ: Lawrence Erlbaum.

Dweck, C. (2006). Mindset: The New Psychology of Success. New York: Random House.

Eccles, J., Wigfield, A., \& Schiefele, U. (1998). Motivation to succeed. In W. Damon (Series Ed.) and N. Eisenberg (Vol. Ed.), Handbook of child psychology ( $5^{\text {th }}$ ed., Vol. 3, pp. 1017-1095). New York: Wiley.

Eagly, A. H. \& Chaiken, S. (1993). The Psychology of Attitudes. New York: Harcourt Brace.

Ehrman, M. E. \& Dornyei, Z. (1998). Interpersonal Dynamics in Second Language Education: The Visible and Invisible Classroom. Sage, Thousand Oaks, CA.

Ellis, R. (2009). Corrective feedback and teacher development. L2 Journal, 1, 3-18.
Feuerstein, R., Feuerstein, R. S., \& Schur, Y. (1997). Process as content in education of exceptional children. In R. Feuerstein, R. S. Feuerstein, \& A. Kozulin (Eds.), The ontogeny of cognitive modifiability: Applied aspects of mediated learning experience and instrumental enrichment (pp. 1-24). Jerusalem, Israel: International Centre for the Enhancement of Learning Potential.

Field, J. (2007). Looking outwards, not inwards. ELT Journal 61(1), 30-38.

Fiske, S.T. (2004). Social Beings: A core motive approach to social psychology. New York: Wiley

Fiske, S.T. (2008). Core social motivations: Views from the couch, consciousness, classroom, computers, and collectives. In: Shah JY, Gardner WL, (Eds.), Handbook of motivation science. NY: Guilford Press.

Flege, J. E. (2009). Give input a chance! In T. Piske \& M. Young-Scholten (Eds.), Input matters in SLA (pp. 175-190). Clevedon: Multilingual Matters.

Ford, M. (1992). Motivating Humans: Goals, Emotions and Personal Agency Beliefs. Newbury Park, CA: Sage.

Gao, Y., Zhao, Y., Cheng, Y., \& Zhou, Y. (2003). Motivation types of Chinese college undergraduates. Modern Foreign Languages (Quarterly), 26(1), 28-38.

Gardner, R.C. (1985). Social Psychology and Second Language Learning: The Role of Attitudes and Motivation. London: Edward Arnold.

Gay, G. (2010). Culturally responsive teaching: Theory, research, and practice. New York, NY: Teachers College Press. doi:10.4324/9780203874783.ch13

Goldberg, L. R. (1981). Language and individual differences: The search for universals in personality lexicons. In: Wheeler L., editor. Review of personality and social psychology. Beverly Hills, CA: Sage; p. 141-65. 
Graham, S. (2006). Listening comprehension: The learners' perspective. System 34, 165182.

Griffiths, C. (2013). The strategy factor in successful language learning. Bristol, England: Multilingual Matters.

Grouzet, F., Kasser. T., Ahuvia. A., Dols. J., Kim. Y., Lau. S., (2005). The structure of goal contents across 15 cultures. Journal of Personality and Social Psychology. 89(80), 0-16.

Harley, B. (2000). Listening strategies in ESL: Do age and L1 make a difference? TESOL Quarterly 34, 769-776.

Harris, V. (2007). Exploring Progression: Reading and Listening Strategy Instruction with Near Beginner Learners of French. Language Learning Journal, 35(2), 189-204.

Henry, A., \& Cliffordson, C. (2013). Motivation, gender, and possible selves. Language Learning, 63, 271-295. doi:10.1111/lang.12009

Henry, A., Davydenko, S., \& Dörnyei, Z. (2015). The anatomy of directed motivational currents: Exploring intense and enduring periods of L2 motivation. Modern Language Journal, 99, 329-345.

Herdina, P. \& Jessner, U. (2002). A Dynamic Model of Multilingualism: Changing the Psycholinguistic Perspective. Clevedon: Multilingual Matters.

Hiver, P., \& Al-Hoorie, A. H. (2016). A dynamic ensemble for second language research: Putting Complexity Theory into practice. Modern Language Journal, 100, 741-756.

Hohenberger, A., \& Peltzer-Karpf, A. (2009). Language learning from the perspective of nonlinear dynamic systems. Linguistics, 47, 481-511. doi:10.1515/LING.2009.017

Huensch, A., \& Thompson, A. S. (2017). Contextualizing attitudes toward pronunciation: Foreign language learners in the US. Foreign Language Annals, 50(2), 410-432.

Jessner, U. (2006). Linguistic Awareness in Multilinguals. Edinburgh: Edinburgh University Press.

Jessner, U. (2008). A DST model of multilingualism and the role of metalinguistic awareness. Modern Language Journal, 92, 270-283.

Joe, H.-K., Hiver, P., \& Al-Hoorie, A. H. (2017). Classroom social climate, self-determined motivation, willingness to communicate, and achievement: A study of structural relationships in instructed second language settings. Learning and Individual Differences, 53, 133-144.

Kaldi, S., Filippatou, D., \& Govaris, C. (2011). Project-based learning in primary schools: Effects on pupils' learning and attitudes. Education, 13(39), 35-47.

Kana'iaupuni, S., Ledward, B., \& Jensen, U. (2010). Culture-based education and its relationship to student outcomes. Honolulu, Hawai'i: Kamehameha Schools Research and Evaluation.

Katz, L. G., Chard, S. C., \& Kogan, Y. (2014). Engaging children's minds: The project approach (3rd ed.). Santa Barbara, CA: Praeger.

Kim, N. (2005). Using a project-based learning approach in Korean EFL classrooms. English Language \& Literature Teaching, 11(1), 57-76.

Kim, T. Y. (2009). Korean elementary school students' perceptual learning style, ideal L2 self, and motivated behavior. Korean Journal of English Language and Linguistics, 9, 461-486. doi:10.15738/kjell.9.3.200909.461

Kim, Y. K., \& Kim, T. Y. (2011). The effect of Korean secondary school students' perceptual learning styles and ideal L2 self on motivated L2 behavior and English proficiency. Korean Journal of English Language and Linguistics, 11, 21-42. 
Kormos, J., \& Csizér, K. (2008). Age-related differences in the motivation of learning English as a foreign language: Attitudes, selves, and motivated learning behavior. Language Learning, 58, 327-355.

Lamb, M. (2012). A self system perspective on young adolescents' motivation to learn English in urban and rural settings. Language Learning, 62(4), 997-1023.

Lantolf, J (2000). Sociocultural theory and second language learning, pp. 27-50. Oxford: Oxford University Press. Educational Psychologist, 48(3), 135-147.

Lanvers, U. (2016). Lots of selves, some rebellious: Developing the self discrepancy model for language learners. System, 60, 79-92.

Larmer, L., Mergendoller, J., \& Boss, S. (2015). Setting the standard for project-based learning. Alexandria, VA: ASCD.

Larsen-Freeman, D. (2017). Complexity Theory: The Lessons Continue. In Complexity Theory and Language Development: In Honor of Diane LarsenFreeman, edited by L. Ortega and Z.-H. Han. Amsterdam: John Benjamins.

Larsen-Freeman, D. (2015). Ten 'lessons' from Complex Dynamic Systems Theory: What is on offer. In Z. Dörnyei, P. D. MacIntyre, \& A. Henry (Eds.), Motivational dynamics in language learning (pp. 11-19). Bristol, UK: Multilingual Matters.

Larsen-Freeman, D., \& Cameron, L. (2008). Complex systems and applied linguistics. Oxford: Oxford University Press.

Lechago, S. A., Carr, J. E., Grow, L. L., Love, J. R., \& Almason, S. M. (2010). Mands for information generalize across establishing operations. Journal of Applied Behavior Analysis, 43, 381395. https://doi.org/10.1901/jaba.2010. 43-381

Legutke, M., \& Thomas, H. (2013). Process and experience in the language classroom. New York, NY: Routledge.
Levy, M. (2015). The role of qualitative approaches to research in CALL contexts: Closing in on the learner's experience. CALICO Journal, 32(3), 554-568.

Lewin, K. (1951). Field Theory in Social Science, New York, NY, USA: Harpers.

Li, K. (2009). A study on motivational regulation strategies of Chinese EFL college students. Modern Foreign Languages, 32(3), 305-313.

Liu, N. F. (2003). Processing problems in L2 listening comprehension of university students in Hong Kong. Ph.D. Dissertation, Hong Kong Polytechnic University.

Liu, Y., \& Thompson, A. S. (2018). Language learning motivation in China: An exploration of the L2MSS and psychological reactance. System, 72, 3748.

Lopes-Murphy, S. (2012). Universal Design for Learning: Preparing secondary education teachers in training to increase academic accessibility of high school English learners. The Clearing House: A Journal of Educational Strategies, Issues and Ideas, 85(6), 226-230. doi:10.1080/00098655.2012.693549

Lyster, R. (2004). Differential effects of prompts and recasts in form-focused instruction. Studies in Second Language Acquisition, 26, 399-432.

Lyubomirsky, S., \& Layous, K. (2013). How do simple positive activities increase wellbeing? Current Directions in Psychological Science, 22, 57-62. doi:10.1177/0963721412469809

Ma, G. (2005). The effects of motivation and effort on foreign language achievement. Journal of PLA University of Foreign Languages, 28(4), 37-41.

Maslow, A.H. (1970). Motivation and Personality. New York: Harper and Row.

Maehr, M. L. (1984). Meaning and motivation: Toward a theory of personal investment. 
In R. E. Ames \& C. Ames (Eds.), Research on motivation in education (pp. 115-144). New York: Academic Press.

Markham, T., Larmer, J., \& Ravitz, J. (2003). Project-based learning handbook: A guide to standards-focused project-based learning for middle and high school teachers. Novato, CA: BIE.

McCafferty, S. G. (2008). Gesture and the materialization of second language prosody. International Review of Applied Linguistics in Language Teaching, 44, 197209. doi:10.1515/IRAL.2006.008

Mercer, S. (2015). Learner Agency and Engagement: Believing You Can, Wanting To, and Knowing How To. Humanizing Language Teaching 17 (4), 1-19.

Mills, N. (2014). Self-efficacy in second language acquisition. In S. Mercer, \& M. Williams (Eds.), multiple perspectives on the self in SLA (pp. 6-22). Bristol, England: Multilingual Matters.

Moskovsky, C., Racheva, S., Assulaimani, T., \& Harkins, J. (2016). The L2 Motivational Self System and L2 Achievement: A study of Saudi EFL learners. The Modern Language Journal. Advanced online publication. doi: 10.1111/modl.12340

Nakatani, Y. \& C. Goh (2007). A review of oral communication strategies: Focus on interactionist and psycholinguistic perspectives. In A. Cohen (ed.), Language learner strategies: Thirty years of research and practice. Oxford: Oxford University Press, 207-227.

O’Reilly, E. (2012). Language Counseling Trends: Implications for Beginning Language Learning Strategy Instruction. Studies in Self-Access Learning Journal 3 (4), 438-451.

Onatsu-Arvolommi, T., Nurmi, J.-E., \& Aunola, K. (2002). The development of achievement strategies and academic skills during the first year of primary school. Learning and Instruction, 12, 509527.
Oxford, R. (2017). Teaching and researching language learning strategies: Selfregulation in context (2nd ed.). New York: Routledge.

Panadero, E., \& J. Alonso-Tapia. (2014). How Do Students Self-Regulate? Review of Zimmerman's Cyclical Model of SelfRegulated Learning. Anales de Psicología/Annals of Psychology, 30 (2), 450-462.

Pica, T. (2002). Subject-matter content: How does it assist the interactional and linguistic needs of classroom language learners? The Modern Language Journal, 86, 1-19.

Quoidbach, J., Mikolajczak, M., \& Gross, J. J. (2015). Positive interventions: An emotion regulation perspective. Psychological Bulletin, 141, 655-693. doi:10.1037/a0038648

Rosales, R., \& Rehfeldt, R. A. (2007). Contriving transitive conditioned establishing operations to establish derived manding skills in adults with severe developmental disabilities. Journal of Applied Behavior Analysis, 40, 105-121. https://doi.org/ 10.1901/jaba.2007.117-05

Rubio, F. (2014). Self-esteem and self-concept in foreign language learning. In S. Mercer, \& M. Williams (Eds.), multiple perspectives on the self in SLA (pp.41-58). Bristol, England: Multilingual Matters.

Rusk, R. D., \& Waters, L. (2015). A psychosocial system approach to well-being: Empirically deriving the five domains of positive functioning. The Journal of Positive Psychology, 10, 141-152. doi:10.1080/17439760.2014.920409

Ryan, S. (2009). Self and identity in L2 motivation in Japan: The ideal L2 self and Japanese learners of English. In Z. Dörnyei \& E. Ushioda (Eds.), Motivation, language identities and the L2 self (pp. 120-143). Bristol, UK: Multilingual Matters.

Saito, K. (2015). Experience effects on the development of late second language 
learners' oral proficiency. Language Learning, 65, 563-595.

Sansone, C., \& Thoman, D. B. (2005). Interest as the missing motivator in self-regulation. European Psychologist, 10, 175-186.

Schmidt, H. G., Loyens, S. M. M., van Gog, T., \& Paas, F. (2007). Problem-based learning is compatible with human cognitive architecture: Commentary on Kirschner, Sweller, and Clark (2006). Educational Psychologist, 42, 91-97.

Schunk, D. H., \& Pajares, F. (2005). Competence beliefs in academic functioning. In A. J. Elliot, \& C. Dweck (Eds.), Handbook of competence and motivation (pp.85-104). New York: Guilford Press.

Schunk, D. H., \& Zimmerman, B. J. (2012). Motivation and self-regulated learning: Theory, research, and applications. New York: Routledge.

Schwartz, S. H., \& Bilsky. W. (1987). Toward a universal psychological structure of human values. Journal of Personality and Social Psychology. 53(3), 550-62.

Schwartz, S. H, Cieciuch. J., Vecchione. M., Davidov. E., Fischer. R., \& Beierlein. C., (2012). Refining the theory of basic individual values. Journal of Personality and Social Psychology. 103(4), 663-88.

Schwinger, M., Steinmayr, R., \& Spinath, B. (2009). How do motivational regulation strategies affect achievement: Mediated by effort management and moderated by intelligence. Learning and Individual Differences, 19(4), 621-627.

Segalowitz, N., \& Trofimovich, P. (2012). Second language processing. In S. Gass \& A. Mackey (Eds.), The Routledge handbook of second language acquisition (pp. 179192). New York: Routledge/Taylor \& Francis.

Seifoori, Z. \& Z. Vahidi (2012). The impact of fluency strategy training on Iranian EFL learners' speech under on line planning conditions. Language Awareness 21(2), 101-112.

Serafini, E. J. (2013). Cognitive and psychosocial factors in the long-term development of implicit and explicit second language knowledge in adult learners of Spanish at increasing proficiency. (Unpublished doctoral dissertation). Georgetown University, Washington, DC.

Serafini, E. J. (2017). Exploring the dynamic long-term interaction between cognitive and psychosocial resources in adult second language development at varying proficiency. The Modern Language Journal, 101, 2, doi: 10.1111/modl.12400

Sheldon, K., Boehm, J., \& Lyubomirsky, S. (2013). Variety is the spice of happiness: The hedonic adaptation prevention (HAP) model. In S. A. David, I. Boniwell, \& A. C. Ayers (Eds.), Oxford handbook of happiness (pp. 901-914). Oxford: Oxford University Press.

Sivan, E. (1986). Motivation in social constructivist theory. Educational Psychologist, 21, 209-233.

Smotrova, T. (2017). Making Pronunciation Visible: Gesture in Teaching Pronunciation. TESOL Quarterly, 51 (1), 130. doi: 10.1002/tesq.276

Stoller, F. (2006). Establishing a theoretical foundation for project-based learning in second and foreign language contexts. In G. H. Beckett, \& P. C. Miller (Eds.), Projectbased second and foreign language education: Past, present, and future (pp. 19-40). Greenwich, CT: Information Age.

Swain, M. (1995). Three functions of output in second language acquisition. In G. Cook \& B. Seidlhofer (eds.), Principle and practice in applied linguistics. Oxford: Oxford University Press, 125-144.

Swain, M. (1997). Collaborative dialogue: Its contribution to second language learning. Revista Canaria de Estudios Ingleses, 34, 115-132. 
Snyder, C. R. (2002). “Hope Theory: Rainbows in the Mind." Psychological Inquiry 13, 249-275.

Triplett, N. (1898). The dynamogenic factors in pacemaking and competition, The American Journal of Psychology, 9 (4), 507-533.

Thompson, A. S. (2017). Don't tell me what to do! The anti-ought-to self and language learning motivation, System, 67, 38-49.

Thompson, A. S., \& Erdil-Moody, Z. (2016). Operationalizing multilingualism: Language learning motivation in Turkey. International Journal of Bilingual Education and Bilingualism, 19(3), 314331.

Thompson, A. S., \& Liu, Y. (2018). Multilingualism and emergent selves: Further development of the anti-ought-to self. Manuscript submitted for publication. International Journal of Bilingual Education and Bilingualism. https://doi.org/10.1080/13670050.201 8.1452892

Thompson, A. S., \& Vasquez, C. (2015). Exploring motivational profiles through language learning narratives. Modern Language Journal, 99(1), 158-174. http://dx.doi.org/10.1111/modl.12187

Ushioda, E. (2013). Foreign language motivation research in Japan: An 'insider' perspective from outside Japan. In M. T. Apple, D. Da Silva \& T. Fellner (Eds.), Language learning motivation in Japan (pp. 1-14). Clevedon, UK: Multilingual Matters.

Ushioda, E. \& Dörnyei, Z. (2012). Motivation. In S. Gass and A. Mackey (eds) The Routledge Handbook of Second Language Acquisition (pp. 396-409). Abingdon: Routledge.

Ushioda, E. (2014). Motivational perspectives on the self in SLA: A developmental view. In S. Mercer \& M. Williams (eds.), Multiple perspectives on the self in SLA. Bristol: Multilingual Matters, 127-141.
Van Geert, P. (2011). The Contribution of Complex Dynamic Systems to Development. Child Development Perspectives, 5, 273-278.

Van Lier, L. (2002). An ecological-semiotic perspective on language and linguistics. In C. Kramsch (Ed.), Language acquisition and language socialization: Ecological perspectives (pp. 140-164). London: Continuum.

Wallace, M. D., Iwata, B. A., \& Hanley, G. P. (2006). Establishment of mands following tact training as a function of reinforce strength. Journal of Applied Behavior Analysis, 39, 1724. https://doi.org/10.1901/jaba.2006.1 19-04

Waninge, F., Dörnyei, Z., \& de Bot, K. (2014). Motivational dynamics in language learning: Change, stability, and context. Modern Language Journal, 98, 704-723.

Weiner, B. (1994). Integrating social and personal theories of achievement motivation. Review of Educational Research, 64, 557-573.

Weiner, B. (1992). Human Motivation: Metaphors, Theories and Research. Newbury Park, CA: Sage. Cambridge University Press.

Wentzel, K. R. (1999). Social-motivational processes and interpersonal relationships: Implications for understanding motivation at school. Journal of Educational Psychology, 91, 7697.

Wolters, C. A. (2003). Regulation of motivation: Evaluating an underemphasized aspect of self-regulated learning. Educational Psychologist, 38(4), 189-205.

Wolters, C. A., \& Benzon, M. B. (2013). Assessing and predicting college students' use of strategies for the self-regulation of motivation. Journal of Experimental Education, 81(2), 199-221. 
You, C., Dornyei, Z. \& Csiz'er, K. (2016). Motivation, Vision, and Gender: A Survey of Learners of English in China, Language Learning 66(1), 94-123. doi: 10.1111/lang.12140

Young, Andrea S. (1994). Motivational state and process within the sociolinguistic context, an Anglo-French comparative study of school pupils learning foreign languages. Unpublished $\mathrm{PhD}$ thesis. University of Aston, Birmingham.

Zhang,Y., \& Lin, C. H., \& , Zhang, D., \& Choi, Y. (2016). Motivation, strategy, and English as a foreign language vocabulary learning: A structural equation modeling study. British Journal of Educational Psychology. doi: 10.1111/bjep.12135

Zimmerman, B. J. (2013). From cognitive modeling to self-regulation: A social cognitive career path. Educational Psychologist, 48(3), 135-147.

Zimmerman, B. J., \& Kitsantas, A. (2005). The hidden dimension of personal competence: Self-regulated learning and practice. In A. J. Elliot, \& C. S. Dweck (Eds.), Handbook of competence and motivation (pp. 509526). New York: Guilford Press. 